\title{
Strategies for appropriate antibiotic use in intensive care unit
}

\author{
Estratégias para uso adequado de antibioticoterapia em unidade de terapia intensiva
}

\author{
Camila Delfino Ribeiro da Silva ${ }^{1}$, Moacyr Silva Júnior ${ }^{1}$
}

\begin{abstract}
The comsumption of antibiotics is high, mainly in intensive care units. Unfortunately, most are inappropriately used leading to increased multi-resistant bacteria. It is well known that initial empirical therapy with broad-spectrum antibiotics reduce mortality rates. However the prolonged and irrational use of antimicrobials may also increase the risk of toxicity, drug interactions and diarrhea due to Clostridium difficile. Some strategies to rational use of antimicrobial agents include avoiding colonization treatment, de-escalation, monitoring serum levels of the agents, appropriate duration of therapy and use of biological markers. This review discusses the effectiveness of these strategies, the importance of microbiology knowledge, considering there are agents resistant to Staphylococcus aureus and Klebsiella pneumoniae, and reducing antibiotic use and bacterial resistance, with no impact on mortality.
\end{abstract}

Keywords: Antibacterial agents; Drug utilization; Intensive care units

\section{RESUMO}

0 consumo de antibióticos é elevado, principalmente nas unidades de terapia intensiva. Infelizmente, a maior parte desse uso é inadequado e favorece o aumento de bactérias multirresistentes. Sabe-se que a terapia empírica inicial de amplo espectro diminui a mortalidade, porém o uso prolongado e irracional dos antimicrobianos, além da multirresistência, pode elevar o risco de toxicidade, de interações medicamentosas e de diarreia por Clostridium difficile. Algumas estratégias para o uso racional de antimicrobianos incluem evitar tratamento de colonização, descalonamento, monitorização do nível sérico dos antimicrobianos, duração adequada de tratamento e uso de marcadores biológicos. Esta revisão discute a efetividade dessas estratégias, bem como a importância de conhecimentos em microbiologia, devido a alguns agentes resistentes como Staphylococcus aureus e Klebsiella pneumoniae, para redução tanto do consumo de antimicrobianos como da resistência bacteriana, sem impacto em mortalidade.

Descritores: Antibacterianos; Uso de medicamentos; Unidades de terapia intensiva

\section{INTRODUCTION}

Antimicrobials are one of the major drugs used in intensive care units (ICU), although their undiscriminating and prolonged use is one of the main factors involved in the emergence of multidrug-resistant bacteria, whose incidence has grown in all continents. ${ }^{(1)}$

One example from data collected between 2004 and 2009 on bloodstream infections in the ICU of several countries showed that Staphylococcus aureus isolated were methicillin-resistant in $84.4 \%$ of cases; $100 \%$ of cases of Pseudomonas aeruginosa were resistant to cefepime and $47.2 \%$ to carbapenems; $76.3 \%$ of cases of Klebsiella pneumoniae and $66.7 \%$ of Escherichia coli were resistant to ceftriaxone; and $55.3 \%$ of Acinetobacter baumannii cases were resistant to carbapenems. ${ }^{(2)}$

Meanwhile, there has been a reduction in the availability of new antimicrobials in the market. This is also due to the fast emergence of strains resistant to new drugs, which possibly dampens more investments. ${ }^{(2)}$

Thus, the best way to reduce the emergence of resistant strains, especially in ICUs, is the rational use of antimicrobial strategies, such as practicing de-escalation; avoiding colonization treatment; evaluating serum levels of antimicrobials and adequate antibiotic treatment duration; and using biological markers such as procalcitonin, for example, that enable differentiating cases of infectious from non-infectious etiology. ${ }^{(3,4)}$

De-escalation is the adjustment of the antimicrobial regimen according to culture results, that is, changing a regimen with more drugs and/or drugs with a broader spectrum by using another regimen with fewer drugs and/or drugs with a more narrow spectrum, but more sensitive on the antibiogram..$^{(5,6)}$

\footnotetext{
Hospital Israelita Albert Einstein, São Paulo, SP, Brazil

Corresponding author: Camila Delfino Ribeiro da Silva - Avenida Albert Einstein, 627/701, 5th floor, building A - Morumbi - Zip code: $05651-901$ - São Paulo, SP, Brazil - Phone: (55 11) 2151-1520 E-mail: camila.ribeiro@einstein.br

Received on: Apr 9, 2014 - Accepted on: Jan 6, 2015

DOI: 10.1590/\$1679-45082015RW3145
} 


\section{COLONIZATION VERSUS INFECTION}

A common problem observed in the abuse of antimicrobials is treating colonized patients. This happens when antibiotic treatment is introduced due to a positive culture, despite no signs or symptoms of infection. This is the case, for example, of tracheal secretion, urine or tip of central venous catheter cultures.

Knowing the microbiota that colonizes the patient may help in cases in which empirical treatment is necessary, as shown by Blot et al. ${ }^{(7)}$ The acknowledgement of colonization previous to infection was associated with higher rates of adequate treatment in patients that developed bacteremia. ${ }^{(7)}$

\section{KLEBSIELLA PNEUMONIAE CARBAPENEMASE-PRODUCING BACTERIA}

In the multiresistance scenario, carbapenemase-producing Gram-negative (carbapenem inactivating enzymes) stand out, especially Klebsiella pneumoniae (KPC). Infections caused by these agents are important in terms of morbidity and mortality and their treatment is challenging. ${ }^{(8)}$

Automated systems frequently report antibiogram results with agents susceptible to imipenem and meropenem, in vitro. Therefore, confirmatory tests are recommended in the presence of strains with decreased sensitivity to carbapenems or resistance to most other beta-lactam drugs. ${ }^{(8)}$

\section{ANTIMICROBIAL DE-ESCALATION}

Empirical broad-spectrum treatment aims to use drugs with wider antimicrobial coverage, boosting therapeutics, and reducing mortality and bacterial resistance..$^{(3-6,9,10)} \mathrm{On}$ the other hand, the high consumption of antimicrobials leads to higher risk of toxicity, drug interaction, and in the long term, higher incidence of diarrhea due to Clostridium difficile. ${ }^{(3,4)}$

Unfortunately, there are no protocols guiding which is the best association of antimicrobials according to each infection site. Therefore, the empirical association of antibiotics occurs according to local epidemiology, patient clinical presentation and risk factors. ${ }^{(9,10)}$

For empirical treatment protocols in septic patients, broad-spectrum treatment is recommended to reduce mortality, ${ }^{(5,6,11)}$ with the recommendation of collecting cultures before beginning treatment and de-escalation, as soon as possible, after microbiology results. ${ }^{(5,6,11)}$

There are countless studies showing safety and efficacy of de-escalation, although there are no randomized studies. ${ }^{(11-14)}$
Shime et al. ${ }^{(12)}$ assessed the efficacy and safety of de-escalation in a study on Gram-negative bacteremia. Although de-escalation was indicated to all patients, it was conducted only in $57 \%$ of cases. There were no cases of treatment failure or reduction in costs.

Joung et al. ${ }^{(13)}$ assessed the impact of de-escalation in mortality of patients with pneumonia, in ICU. The practice aimed to evaluate the decrease in number and spectrum of antimicrobials. There was a trend toward lower pneumonia-related mortality in 14 days, but without statistical significance. However, 30-day mortality was significantly lower in patients submitted to de-escalation.

Morel et al. ${ }^{(14)}$ also reported that there was no increase in mortality with de-escalation in general infections at the ICU.

\section{ANTIMICROBIAL SERUM LEVELS}

Using antimicrobials without the availability of serum dosages may be complicated in several scenarios, because of obesity, renal failure, hemodynamic instability and severe infections. If one cannot assess if a drug is used at a therapeutic level, there may be treatment failure, toxicity and adverse events. ${ }^{(15)}$

Several studies on sepsis and septic shock have already made it clear that the early administration of antimicrobials reduces mortality rates, although there is little information available on adequate dosage regimens and clinical outcomes. ${ }^{(5,6)}$

Van Lent-Evers et al. published a randomized controlled study that monitored serum aminoglycosides, with an impact on length of stay. ${ }^{(16)}$

\section{VANCOMYCIN SERUM LEVELS}

Throughout the years, vancomycin has been one of the most studied antimicrobials with several pharmacokinetic analyses, and in a variety of populations. Serum concentration aims to minimize adverse events and to reach adequate concentrations, decreasing treatment failure rates. ${ }^{(17-19)}$

Vancomycin is a glycopeptide antimicrobial available for clinical use for over 50 years, when there were not many options to treat penicillin-resistant Staphylococcus infections. ${ }^{(20)}$

Initially, vancomycin was associated with countless adverse events, including toxicities related to infusion, nephrotoxicity and ototoxicity. ${ }^{(20)}$ The events were possibly related to initial formulations, considered more impure. ${ }^{(20)}$ The use of vancomycin was significantly reduced with the emergence of semisynthetic penicillins 
(methicillin and oxacillin, for example), considered less toxic. ${ }^{(20)}$

However, as of the 1980's, there was an expressive growth in the use of vancomycin. ${ }^{(21)}$ This happened due to the progressive increase in infections due to resistant agents, mainly methicillin-resistant Staphylococcus aureus (MRSA) infections. ${ }^{(21)}$

In a systematic review of 15 studies that evaluated nephrotoxicity while using vancomycin, the incidence ranged between 5 and $43 \%$. Higher serum levels of the drug $(\geq 15 \mathrm{mg} / \mathrm{dL})$ were associated with increased renal toxicity, occurring more frequently in patients with other risk factors, such as admission to an intensive care unit. ${ }^{(22)}$

Forstner et al. ${ }^{(23)}$ performed a retrospective analysis of patients with methicillin-resistant Staphylococcus bacteremia, and found the level of vancomycin as a predictor factor of mortality; in that, only $22.6 \%$ of patients reached recommended serum levels of the drug.

In 2013, a Chinese group published a revision and meta-analysis of studies that assessed the benefit of monitoring serum vancomycin, with significantly higher rates of clinical efficacy and less nephrotoxicity in patients submitted to the practice. ${ }^{(24)}$

In 2006, the Clinical and Laboratory Standards Institute (CLSI) decreased the minimum inhibitory concentration (MIC) breakpoint of vancomycin susceptibility from $4 \mathrm{mg} / \mathrm{L}$ to $<2 \mathrm{mg} / \mathrm{L}$ for MRSA. Despite this fact, there is frequent concern, given there is a historical decrease in sensitivity of MRSA to glycopeptides, a phenomenon called "MIC creep". ${ }^{(25,26)}$ This means that there is a change in the MIC pattern of vancomycin among populations of Staphylococcus aureus considered susceptible, generating a subpopulation with reduced sensitivity to the drug. It is essential that individuals with suspected infection by these strains be evaluated judiciously, with advanced microbiology knowledge, for adequate antimicrobial treatment.

Several studies reported worse outcomes in patients who developed MRSA infections with higher MIC. ${ }^{(27-29)}$ A systematic review and meta-analysis published in 2012 observed that the higher the level of vancomycin, the higher the mortality rate, regardless of the infection source. ${ }^{(27,28)}$

Sakoulas et al. ${ }^{(29)}$ evaluated the relation between MIC and the bactericidal efficacy of vancomycin to treat MRSA bacteremia, and found a positive correlation between in vitro bactericidal activity and clinical success.

Strains of glycopeptide intermediate-resistant $S$. aureus (GISA) have been described in the past years. Infections by these agents are still not very frequent, but the concern is that the prevalence can grow due to high use and to exposure to vancomycin. ${ }^{(21)}$
The most recent recommendations for vancomycin use in adults by the Infectious Diseases Society of America (IDSA) were published in 2009 and are displayed in chart 1 . The serum concentration is described as the most accurate and practical way to monitor drug efficacy. A higher level is recommended, with aggressive monitoring, depending on the kind of infection, such as 15 to $20 \mathrm{mg} / \mathrm{dL}$ for bacteremia, endocarditis, osteomyelitis, meningitis and nosocomial Staphylococcus aureus pneumonia. ${ }^{(18,19)}$

Chart 1. Recommendations by the Infectious Diseases Society of America (2009) to adjust therapeutic dose of vancomycin

\begin{tabular}{|ll|}
\hline Dosage & Initial dose should be calculated according to weight, as $25-30 \mathrm{mg} / \mathrm{kg}$ \\
Serum level & Subsequent doses based on serum concentration \\
& $\begin{array}{l}\text { More effective and practical method } \\
\text { Should be obtained immediately before the fourth dose, for patients with } \\
\text { normal kidney function } \\
\text { Recommendation: } 15-20 \mathrm{mg} / \mathrm{dL} \text { every } 8 \text { to } 12 \text { hours }\end{array}$
\end{tabular}

\section{LENGTH OF TREATMENT PERIOD AND USE OF PROCALCITONIN}

There has been ample discussion in the literature on length of treatment of both community and health care-related infections.

Short-term treatments have several advantages, but may not eradicate the microorganism, increasing the likelihood of relapses, mainly for non-fermenting Gram-negative bacteria. ${ }^{(30-33)}$ Longer treatments may be related to higher toxicity, adverse events, higher risk of candidemia diarrhea due to Clostridium difficile. ${ }^{(30)}$

Many factors influence the medical decision regarding length of antimicrobial treatment, such as characteristics of the microorganism, of the patient, infection and of the drugs available for treatment (Chart 2). ${ }^{(30)}$

Chart 2. Factors that influence length of antimicrobial treatment

\begin{tabular}{|ll|}
\hline Microorganism characteristics & Sensitivity profile \\
& Biofilm formation capacity \\
& Metastatic focus potential \\
& Virulence \\
Patient characteristics & Immunological status (age, comorbidity and \\
& immunosuppressing treatments) \\
& Presence of foreign body (metal prothesis, valve \\
& implant, catheter, etc.) \\
& Duration \\
Infection characteristics & Location \\
& Severity and response to treatment \\
Antimicrobial characteristics & Profile of microorganism sensitivity \\
& Bactericidal versus bacteriostatic \\
& Monotherapy versus combined treatment
\end{tabular}


Chastre et al., ${ }^{(31)}$ compared 8 versus 15 days of treatment for mechanical ventilation-associated pneumonia (MVAP) in a prospective and randomized study. They demonstrated that patients submitted to shorter treatment courses did not differ in mortality or infection recurrence, except for pneumonias caused by non-fermenting Gram-negative bacilli, including Pseudomonas.

Corona et al. ${ }^{(32)}$ also evaluated patients with community and hospital bacteremia; $72.5 \%$ received antimicrobial treatment for a short period, with a median of 5 days, many of which with septic shock, and without harming patient outcome. Pugh et al. ${ }^{(33)}$ evaluated short-term versus long-term antimicrobial treatment efficacy in patients with hospital pneumonia, including MVAP in a systematic review. A 7-to-8 day antibiotic course reduced recurrence of MVAP by multiresistant agents, without harming treatment, except in cases by nonfermenting Gram-negative bacilli.

A new approach to try to determine the real need for antimicrobial treatment and even help in length of treatment, is to use biomarkers such as procalcitonin. ${ }^{(34-39)}$

Procalcitonin is a calcitonin peptide precursor produced as a response to bacterial toxins and, mainly, to pro-inflammatory mediators such as interleukin $1 \mathrm{~b}$, tumor necrosis factor and interleukin 6. The levels of procalcitonin rise within 6 to 12 hours from the beginning of bacterial infection, and are expected to drop after control of the infectious presentation.

The authors of the prospective study PRORATA found a $23 \%$ reduction in the consumption of antimicrobials for patients submitted to a procalcitonin collection protocol, without statistical difference in mortality. ${ }^{(34)}$

A systematic review by Schuetz et al. ${ }^{(35)}$ described safety and efficacy of using procalcitonin for respiratory infections and sepsis. The authors observed an important reduction in exposure to antimicrobials in several scenarios, with no increase in mortality rate: in clinical presentations with little evidence of infection, such as exacerbation of chronic obstructive pulmonary disease and bronchitis; and in shorter treatments in patients with pneumonia and sepsis.

There are several other studies that found lower rates of antimicrobial use in patients submitted to procalcitonin collecting protocols, although there is also some criticism: most investigated respiratory infections; many are inconclusive; standardized criteria are lacking for collecting procalcitonin; and there is no defined cut-off value. In severe patients, the levels of procalcitonin were not used for initiating treatment, but for discontinuing the antimicrobial. However, the drop in biomarker levels correlates with clinical resolution of the infectious process, which allows the safe withdrawal of the antimicrobial agent. ${ }^{(36-39)}$

A recent study by Huang et al., ${ }^{(38)}$ prospectively evaluated the use of procalcitonin for withdrawal of antimicrobial regimens in patients with intra-abdominal infection, with an $87 \%$ reduction in duration of treatment, with no increase in risk of adverse events.

A meta-analysis by Prkno et al. ${ }^{(39)}$ evaluated studies involving patients with severe sepsis treated in the ICU. The authors described a significant reduction in duration of antimicrobial treatment in patients whose therapy was guided by procalcitonin, with no impact on mortality.

Despite several publications showing a possible benefit in using procalcitonin to decrease duration of antimicrobial treatment, there are few cases, many studies do not differentiate clinical from surgical patients, and there are no standardized criteria. ${ }^{(34-39)}$

\section{CONCLUSION}

Bacterial resistance is a growing and global concern, as are high mortality rates in septic patients treated inadequately.

Several strategies for adequate use of antibiotic treatment have been proposed and discussed exhaustively in the literature. There are several benefits, such as not treating colonization, antimicrobial de-escalation, serum dosage of drugs, use of biomarkers, and shorter treatment with no difference in mortality.

Some issues, such as procalcitonin cut-off values, still need to be explained but the meticulous use of this and other strategies can optimize success of treatment and minimize risks due to prolonged and inadequate use of antimicrobials.

\section{REFERENCES}

1. Vincent JL, Rello J, Marshall J, Silva E, Anzueto A, Martin CD, Moreno R, Lipman J, Gomersall C, Sakr Y, Reinhart K; EPIC II Group of Investigators. International study of the prevalence and outcomes of infection in intensive care units. JAMA. 2009;302(21):2323-9.

2. Rosenthal VD, Bijie H, Maki DG, Mehta Y, Apisarnthanarak A, Medeiros EA, Leblebicioglu H, Fisher D, Álvarez-Moreno C, Khader IA, Del Rocío González Martínez M, Cuellar LE, Navoa-Ng JA, Abouqal R, Guanche Garcell H, Mitrev Z, Pirez García MC, Hamdi A, Dueñas L, Cancel E, Gurskis V, Rasslan 0, Ahmed A, Kanj SS, Ugalde OC, Mapp T, Raka L, Yuet Meng C, Thu le TA, Ghazal S, Gikas A, Narváez LP, Mejía N, Hadjieva N, Gamar Elanbya MO, Guzmán Siritt ME, Jayatilleke K; INICC members. International Nosocomial Infection Control Consortium (INICC) report, data summary of 36 countries, for 2004-2009. Am J Infect Control. 2012;40(5):396-407. 
3. Kollef MH. Optimizing antibiotic therapy in the intensive care unit setting. Crit Care. 2001;5(4):189-95. Review.

4. Paterson DL. The role of antimicrobial management programs in optimizing antibiotic prescribing within hospitals. Clin Infect Dis. 2006; 42 Suppl 2:S90-5. Review.

5. Dellinger RP, Levy MM, Rhodes A, Annane D, Gerlach H, Opal SM, Sevransky JE, Sprung CL, Douglas IS, Jaeschke R, Osborn TM, Nunnally ME, Townsend SR, Reinhart K, Kleinpell RM, Angus DC, Deutschman CS, Machado FR, Rubenfeld GD, Webb SA, Beale RJ, Vincent JL, Moreno R; Surviving Sepsis Campaign Guidelines including the Pediatric Subgroup. Surviving sepsis campaign: international guidelines for management of severe sepsis and septic shock: 2012. Crit Care Med. 2013;41(2):580-637.

6. Jones AE, Puskarich MA. The Surviving Sepsis Campaign guidelines 2012: update for emergency physicians. Ann Emerg Med. 2014;63(1)35-47.

7. Blot S, Depuydt P, Vogelaers D, Decruyenaere J, De Waele J, Hoste E, et al. Colonization status and appropriate antibiotic therapy for nosocomial bacteremia caused by antibiotic-resistant gram-negative bacteria in an intensive care unit. Infect Control Hosp Epidemiol. 2005;26(6):575-9.

8. Arnold RS, Thom KA, Sharma S, Phillips M, Kristie Johnson J, Morgan DJ. Emergence of Klebsiella pneumonia carbapenemase-producing bacteria. South Med J. 2011;104(1):40-5. Review.

9. Gamacho-Montero J, Garcia-Garmendia JL, Barrero-Almodovar A, JimenezJimenez FJ, Perez-Paredes C, Ortiz-Leyba C. Impact of adequate empirical antibiotic therapy on the outcome of patients admitted to the intensive care unit with sepsis. Crit Care Med. 2003:31(12):2742-51.

10. Degoricija V, Sharma M, Legac A, Gradiser M, Sefer S, Vucicević Z. Survival analysis of 314 episodes of sepsis in medical intensive care unit in university hospital: impact of intensive care unit performance and antimicrobial therapy. Croat Med J. 2006;47:(3):385-97.

11. Kaye KS. Antimicrobial de-escalation strategies in hospitalized patients with pneumonia, intra-abdominal infections, and bacteremia. J Hosp Med. 2012;7 Suppl 1:S13-21. Review.

12. Shime N, Kosaka T, Fujita N. De-escalation of antimicrobial therapy for bacteraemia due to difficult-to-treat Gram-negative bacilli. Infection. 2013; $41(1): 203-10$

13. Joung MK, Lee JA, Moon SY, Cheong HS, Joo EJ, Ha YE, et al. Impact of de-escalation therapy on clinical outcomes for intensive care unit-acquired pneumonia. Crit Care. 2011;15(2):R79.

14. Morel J, Casoetto J, Jospé R, Aubert G, Terrana R, Dumont A, et al. De-escalation as part of a global strategy of empiric antibiotherapy management. A restrospective study in a medico-surgical intensive care unit. Crit Care. 2010; 14(6):R225

15. Begg EJ, Barclay ML, Kirkpatrick CM. The therapeutic monitoring of antimicrobial agents. Br J Clin Pharmacol. 2001;52 Suppl 1:35S-43S. Review.

16. van Lent-Evers NA, Mathôt RA, Geus WP, van Hout BA, Vinks AA. Impact of goal-oriented and model-based clinical pharmacokinetic dosing of aminoglycosides on clinical outcome: a cost-effectiveness analysis. Ther Drug Monit. 1999;21(1):63-73.

17. Lee P, DiPersio D, Jerome RN, Wheeler AP. Approaching and analyzing a large literature on vancomycin monitoring and pharmacokinetics. J Med Libr Assoc. 2007;95(4):374-80. Review.

18. Rybak M, Lomaestro B, Rotschafer JC, Moellering R Jr, Craig W, Billeter M, et al. Therapeutic monitoring of vancomycin in adult patients: a consensus review of the American Society of Health-System Pharmacists, the Infectious Disease Society of America, and the Society of Infectious Diseases Pharmacists. Am J Health Syst Pharm. 2009;66(1):82-98. Review. Erratum in: Am J Heath Syst Pharm. 2009;66(10): 887.

19. Rybak MJ, Lomaestro BM, Rotschafer JC, Moellering RC, Craig WA, Billeter $M$, et al. Vancomycin therapeutic guidelines: a summary of consensus recommendations from the infectious diseases Society of America, the American Society of Health-System Pharmacists, and the Society of Infectious
Diseases Pharmacists. Clin Infect Dis. 2009 Aug 1:49(3):325-7. Erratum in: Clin Infect Dis. 2009 Nov 1;49(9):1465.

20. Levine DP. Vancomycin: a history. Clin Infect Dis. 2006;42 Suppl 1:S5-12.

21. Stryjewski ME, Corey GR. Methicilin-resistant Staphylococcus aureus: an evolving pathogen. Clin Infect Dis. 2014;58 Suppl 1:S10-9. Review.

22. van Hal SJ, Paterson DL, Lodise TP. Systematic review and meta-analysis of vancomycin-induced nephrotoxicity associated with dosing schedules that maintain troughs between 15 and 20 milligrams per liter. Antimicrob Agents Chemother. 2013;57(2):734-44. Review.

23. Forstner C, Dungl C, Tobudic S, Mitteregger D, Lagler H, Burgmann H Predictors of clinical and microbiological treatment failures in patients with methicilin-resistant Staphylococcus aureus (MRSA) bacteraemia: a retrospective cohort study in a region with low MRSA prevalence. Clin Microbiol Infect. 2013;19(7):E291-7.

24. YeZK, Tang HL, Zhai SD. Benefits of therapeutic drug monitoring of vancomycin: a systematic review and meta-analysis. PloS One. 2013;8(10):e77169. eCollection 2013. Review.

25. Tenover FC, Moellering RC Jr. The rationale for revising the Clinical and Laboratory Standard Institute vancomycin minimal inhibitory concentration interpretative criteria for Staphylococcus aureus. Clin Infect Dis. 2007; 44(9)1208-15. Review.

26. Dhand A, Sakoulas G. Reduced vancomycin suscetibility among clinical Staphylococcus aureus isolates ('the MIC Creep'): implications for therapy. F1000 Med Rep. 2012;4:4.

27. van Hal SJ, Lodise TP, Paterson DL. The clinical significance of vancomycin minimum inhibitory concentration in Staphylococcus aureus infections: a systematic review and meta-analysis. Clin Infect Dis. 2012;54(6):755-71. Review.

28. Jacob JT, DiazGranados CA. High vancomycin minimum inhibitory concentrations and clinical outcomes in adults with methicillin resistant Staphylococcus aures infections: a meta-analysis. Int J Infect Dis. 2013; 17(2):e93-e100.

29. Sakoulas G, Moise-Broder PA, Schentag J, Forrest A, Moellering RC Jr, Eliopoulos GM. Relationship of MIC and bactericidal activity to efficacy of vancomycin for treatment of methicillin-resistant Staphylococcus aureus bacteremia. J Clin Microbiol. 2004;42(6):2398-402.

30. Corey GR, Stryjewski ME, Everts RJ. Short-course therapy for bloodstream infections in immunocompetent adults. Int J Antimicrob Agents. 2009;34 Suppl 4:S47-51.

31. Chastre J, Wolff M, Fagon JY, Chevret S, Thomas F, Wermert D, Clementi E, Gonzalez J, Jusserand D, Asfar P, Perrin D, Fieux F, Aubas S; PneumA Trial Group. Comparison of 8 vs 15 days of antibiotic therapy for ventilator-associated pneumonia in adults: a randomized trial. JAMA. 2003;290(19):2588-98.

32. Corona A, Wilson AP, Grassi M, Singer M. Prospective audit of bacteremia management in a university hospital ICU using a general strategy of short-course monotherapy. J Antimicrob Chemother. 2004;54(4):809-17.

33. Pugh R, Grant C, Cooke RP, Dempsey G. Short-course versus prolongedcourse antibiotic therapy for hospital-acquired pneumonia in critically ill adults. Cochrane Database Syst Rev. 2011;(10):CD007577. Review.

34. Bouadma L, Luyt CE, Tubach F, Cracco C, Alvarez A, Schwebel C, Schortgen F, Lasocki S, Veber B, Dehoux M, Bernard M, Pasquet B, Régnier B, Brun-Buisson C, Chastre J, Wolff M; PRORATA trial group. Use of procalcitonin to reduce patients' exposure to antibiotics in intensive care units (PRORATA trial): a multicenter randomised controlled trial. Lancet. 2010;375(9713):463-74.

35. Schuetz P, Chiappa V, Briel M, Greenwald JL. Procalcitonin algorithms for antibiotic therapy decisions: a systematic review of randomized controlled trials and recommendations for clinical algorithms. Arch Intern Med. 2011; 171(15):1322-31. Review.

36. Nobre V, Harbarth S, Graf JD, Rohner P, Pugin J. Use of procalcitonin to shorten antibiotic treatment duration in septic patients: a randomidez trial. Am J Respir Crit Care Med. 2008;177(5):498-505. 
37. Saeed K, Dryden M, Bourne S, Paget C, Proud A. Reduction in antibiotic use through procalcitonin testing in patients in the medical admission unit or intensive care unit with suspicion of infection. J Hosp Infect. 2011;78(4):289-92.

38. Huang TS, Huang SS, Shyu YC, Lee CH, Jwo SC, Chen PJ, et al. A procalcitoninbased algorithm to guide antibiotic therapy in secondary peritonitis following emergency surgery: a prospective study with propensity score matching analysis. Plos One. 2014;9(3):e90539.

39. Prkno A, Wacker C, Brunkhorst FM, Schlattmann P. Procalcitonin-guided therapy in intensive care unit patients with severe sepsis and septic shock -a systematic review and meta-analysis. Crit Care. 2013;17(6):R291. 